\title{
Cesta k trenérské profesi
}

\section{Embarking on Coaching Profession}

\author{
Vladimír Jůva, Kristýna Tomková
}

Fakulta sportovních studií Masarykovy univerzity

\begin{abstract}
Abstrakt:
Př́spěvek se zabývá vybranými aspekty profese sportovního trenéra. Trenérství - podobně jako dalši sociální profese - patři k velmi komplexním a náročným povoláním a jeho úspěšné vykonávání souvisí s mnoha společenskými, ale i ekonomickými aspekty. Trenérství představuje profesi rozličných podob, která od svých vykonavatelì vyžaduje nejen široké odborné znalosti, ale také osobnostní předpoklady a sociální dovednosti.

Př́spěvek analyzuje data z provedeného dotazníkového šetření, které se týkalo vybraných aspektů kariéry sportovních trenérů. Naprostá většina zkoumaných sportovních trenérů sportovala již v mládí. Ke sportu je přivedli zejména rodiče. K hlavním motivưm pro volbu trenérství patřila potřeba věnovat se dětem, předávat sportovní zkušenosti a préevevšim úsilí pomáhat druhým k úspěchu. Oslovení sportovní trenéři často uvádèjí, že je absolvované vzdělávání dobřre připravilo po stránce teoretické, nedostatečně však na vlastní trenérskou praxi. Hlavni východisko pro zkvalitnění velmi náročné trenérské práce oslovení trenéri prevážně vidí v rozvoji trenérského vzdělávání.
\end{abstract}

\begin{abstract}
:
The paper deals with selected aspects of the sports coach profession. Coaching - like other social professions - is a very complex and demanding profession and its successful performance is related to many social as well as economic aspects. Coaching represents a profession of various forms requiring from its practitioners not only an extensive expert knowledge, but also personal dispositions and social skills.

The paper analyzes data collected by a questionnaire investigation, which covered selected aspects of the careers of sports coaches. The vast majority of examined sports coaches were active athletes at a young age. The interest in sport was sparked in particular by their parents. The main motives for the choice of coaching included the need to look after children, pass on sport experience and in particular sporting effort to help others succeed. The addressed sports coaches often say that the completed training well prepared them as far as theory is concerned, however, they fund it insufficient in terms on their own practice. The main basis for the improvement of their very difficult work is by the addressed coaches mostly seen in coach education.
\end{abstract}

Kličová slova: $\quad$ sportovní trenér, trenérství, profese trenéra, kariéra trenéra, vzděláváni trenérů, dalši vzděláváni trenérů, výzkum trenérů

Key words: $\quad$ sports coach, coaching, coach profession, coach career, coach education, in-service education of coaches, research of coach

\section{ÚVOD}

Rozvoj sportu, a to zejména soutěžního, souvisí s dostatečným počtem kvalitně erudovaných, kvalifikovaných, vyzrálých i dobře motivovaných a sociálně zabezpečených trenérů. Zejména sportovní trenéři totiž ovlivňují celkovou orientaci, kvalitu i edukační potenciál sportovních aktivit. Termín sportovní trenér se v českém kontextu používá „pro označení funkce člověka, který zajištuje a hlavně vede trénink sportovce" (Svoboda 2003, s. 118). Katalogem prací je činnost sportovního trenéra vymezena jako „Zajištování odborné trenérsko-metodické a sportovní přípravy v daném sportovním odvětví", ale také jako „vzdělávací a výchovná činnost...“ a „koordinace trenérsko-metodického procesu př́pravy sportovců..." (Katalog 2002, 2007). Český zákon č. 536/2004 Sb., o pedagogických pracovnících a o změně někte- 
rých zákonů, uvedenou profesi v rámci školských zařízení charakterizuje z pohledu požadavků na vzdělání. Trenér je v tomto zákoně vymezen jako pracovník vykonávající prrímou pedagogickou činnost, který musí mít mj. pro tuto práci odbornou kvalifikaci, je bezúhonný a zdravotně způsobilý.

Na sportovní trenéry jako odborníky, kteří plánují, organizují a především osobně řídí tréninky sportovců, klade současný sport stále vyšší nároky. Zvyšují se požadavky na jejich široké odborné znalosti, jež odpovídají současnému vědeckému rozvoji a které musí umět aplikovat při plánování a vedení sportovního tréninku. Vzrůstající negativní problémy dnešního sportu současně kladou vyšší nároky na sociální a axiologické aspekty trenérské profese. Perspektivám rozvoje trenérské profese se proto věnuje již řadu let zvýšená pozornost (např. Bette 1984, Côté 2006, Cunningham 2001, 2006, Jansa; Dovalil 2009, Sekot 2006, Svoboda 2003, 2007, Treutlein 2001, Trudel; Gilbert 2006), a to včetně rozsáhlých empirických výzkumů (např. Digel 2000, Jansa; Kováŕ 2008a, 2008b, Lavallee 2006, Schierz; Thiele; Fischer 2006, Svoboda 1998, Zindel 2006).

Teoretické koncepce ukazují (např. Borggrefe; Cachay; Thiel 2006, Cunningham 2001, 2006, Côté 2006, Svoboda 2003, 2007, Treutlein 2001, Trudel; Gilbert 2006), že se trenérství týká především práce s lidmi a odpovědného sociálního jednání. Do sociálních vztahů jednotlivých trenérů a do výkonu jejich profese se promítá řada vlivů, zejména zkušenosti z vlastní sportovní dráhy, se svými trenéry, okolnosti vstupu do trenérské profese, kvalita absolvovaného trenérského vzdělávání a patrně i celá řada dalších okolností. Naše výzkumné šetření jsme proto zaměřili na zjištění důvodů, které podstatně ovlivnily cestu ke sportu budoucích sportovních trenérů, na okolnosti jejich volby trenérské profese a na aspekty, které následně determinovaly profesní dráhu zkoumaných trenérů. Jednu z podstatných výzkumných oblastí představovalo hodnocení trenérského vzdělávání prizmatem námi oslovených aktivních sportovních trenérů.

S vybranými dílčími výsledky provedeného empirického šetření jsme již seznámili odbornou veřejnost např. na konferencích Sport a kvalita života (Brno 2008 a 2009) nebo na konferenci České asociace pedagogického výzkumu (Ostrava 2009). Cílem následujícího textu je podat celkové shrnutí výsledků provedeného dotazníkového šetření zaměřeného na vybrané problémy cesty $\mathrm{k}$ trenérské profesi.

\section{METODIKA}

V květnu, červnu a v říjnu roku 2008 jsme uskutečnili kvantitativní dotazníkové výzkumné šetření sportovních trenérů, které navázalo na získaná a zpracovaná data z předvýzkumu, který proběhl v roce 2006. Použitý původní dotazník „Cesta k trenérské profesi“ jsme na základě získaných zkušeností z př̀edvýzkumu modifikovali a distribuovali respondentům prostřednictvím pověřených osob v tištěné a současně v elektronické verzi. Cílem výzkumného šetření bylo získat přehled o vybraných okolnostech vstupu do trenérské profese a působení v ní. Výzkumné šetření mělo deskriptivní charakter, a proto jsme $\mathrm{v}$ rámci jeho př́pravy neformulovali hypotézy.

Výsledky uskutečněného empirického šetření chápeme především jako východisko pro další výzkumy kvantitativního i kvalitativního charakteru, jež probíhají a které dále připravujeme na Katedře pedagogiky sportu Fakulty sportovních studií Masarykovy univerzity. V současnosti se společně s doktorandy naší katedry zaměřujeme na výzkum vzdělávání trenérů atletiky, sjezdového lyžování, veslování a šermu a současně na vzdělávání vybraných trenérů rekreačního sportu (instruktory a cvičitele), a to v České republice i v komparaci s dalšími vybranými státy (Itálie, Německo, Slovensko a USA).

Vzhledem k nízkému počtu respondentů i k povaze výzkumného vzorku uvádíme data pouze v procentuálním vyjádření a současně si uvědomujeme rizika spojená se zobecňováním získaných údajů. Jsme si plně vědomi toho, že jsme do výzkumného souboru zahrnuli trenéry profesionály i dobrovolníky a trenéry různých sportovních odvětví. Je zřejmé, že jejich práce má různá specifika, na která však v našem výzkumném šetření prozatím nebereme ohled.

Distribuovaný dotazník obsahoval čtyři hlavní části zaměřené na následující oblasti zkoumání: cesta trenérů ke sportu, cesta k trenérství, vzdělávání trenérů a profesní kariéra. Dotazník tvořily položky uzavřené (především v části osobní údaje - např. zjištění nejvyššího dosaženého vzdělání), polouzavřené (např. upřesnění dosažené trenérské licence) a otevřené (např. možnost celkového zhodnocení tématu 
dotazníku). K měření názorů a postojů u zkoumaných trenérů jsme v dotazníku využili Likertovy škály, kdy jsme předložili řadu výroků a tvrzení, kterým respondenti přiřazovali svoji míru souhlasu a nesouhlasu v rámci čtyřstupňové škály (zcela souhlasím - spíše souhlasím - spíše nesouhlasím - vůbec nesouhlasím) a dále možnosti $\mathrm{N}$ - nemohu se vyjádřit. Závěr každé dílčí části dotazníku tvořily neukončené věty týkající se trenérské profese, které měli oslovení trenéři na základě vlastní empirie a osobního názoru výstižně doplnit.

Dostupný výzkumný soubor tvořili studenti-trenéři Fakulty sportovních studií Masarykovy univerzity v Brně a další jimi oslovení trenéři ze sportovních klubů a škol. Pro zpracování jsme získali 212 vyplněných dotazníků. Ve skupině respondentů (podrobněji tab. č. 1) převažovali - jako ve většině výzkumů trenérů - trenéři-muži (64,2 \%). Nejmladšímu respondentovi bylo 18, nejstaršímu 75 let, průměrný věk respondentů byl 29 let a nejpočetněji byla zastoupena skupina trenérů do 30 let (72,6 \%). Nejvyšší dosažené vzdělání bylo u 48,1 \% trenérů úplné středoškolské, u 42,4\% trenérů vysokoškolské se sportovním zaměřením a u 9,5\% trenérů vysokoškolské s jiným než sportovním zaměřením. $V$ době empirického šetření vykonávalo 10,4\% respondentů činnost trenéra profesionálně, 32,6\% respondentů poloprofesionálně a $57 \%$ respondentů bez smlouvy, převážně jako dobrovolní pracovníci. $Z$ hlediska velikosti sídla, v němž trenéři působí, se jednalo v $72,1 \%$ o město nad 100000 obyvatel. $15,6 \%$ trenérů mělo 1 . trenérskou tř́du nebo licenci $\mathrm{A}, 32,1 \%$ trenérů 2 . trenérskou třídu nebo licenci $\mathrm{B}$ a $37,7 \%$ 3. trenérskou tř́du nebo licenci C, 4,2 \% trenérů mělo 4 . trenérskou tř́du a 10,4\% trenérů pracovalo bez oficiálního trenérského vzdělání. $Z$ hlediska věku trénovaných sportovců se trenéři věnovali nejčastěji smíšeným skupinám $(51,6 \%)$ a v 37,3\% pak samostatně dětem a mládeži. Z hlediska pohlaví se trenéři př̀evážně věnovali sportovkyním i sportovcům $(87,2 \%)$. Námi oslovení trenéři působili ve 42 různých individuálních a kolektivních sportech, nejčastěji v atletice $(12,3 \%)$, ve fotbalu (11,8 \%), ve volejbalu $(6,6 \%)$, v plavání $(6,1 \%)$ a v basketbalu (4,2 \%).

Tabulka č. 1: Charakteristika výzkumného souboru (údaje v procentech, $\mathrm{N}=212$ )

\begin{tabular}{|c|c|c|}
\hline \multirow{2}{*}{ Pohlaví } & Muži & 64,2 \\
\hline & Ženy & 35,8 \\
\hline \multirow{4}{*}{ Věk } & $18-30$ let & 72,6 \\
\hline & $31-45$ let & 18,9 \\
\hline & $46-60$ let & 7,1 \\
\hline & 61 let a více & 1,4 \\
\hline \multirow{3}{*}{ Nejvyšší dosažené vzdělání } & Úplné středoškolské & 48,1 \\
\hline & Vysokoškolské - sportovní zaměření & 42,4 \\
\hline & Vysokoškolské - nesportovní zaměření & 9,5 \\
\hline \multirow{3}{*}{ Trenérská zkušenost } & Profesionální & 10,4 \\
\hline & Poloprofesionální & 32,6 \\
\hline & Dobrovolná (bez smlouvy) & 57,0 \\
\hline \multirow{3}{*}{ Velikost sídla působnosti trenéra } & Město (nad 100000 obyvatel) & 72,1 \\
\hline & Menší město (od 2000 do 100 000) & 14,6 \\
\hline & Vesnice (do 2000 obyvatel) & 13,3 \\
\hline \multirow{5}{*}{$\begin{array}{l}\text { Trenérská třída } \\
\text { (trenérská licence) }\end{array}$} & 1. (A) & 15,6 \\
\hline & 2. (B) & 32,1 \\
\hline & 3. (C) & 37,7 \\
\hline & 4. a jiné (např. instruktor) & 4,2 \\
\hline & Bez trenérské třídy & 10,4 \\
\hline
\end{tabular}




\begin{tabular}{|l|l|c|}
\hline \multirow{3}{*}{$\begin{array}{l}\text { Trénovaní sportovci } \\
\text { podle věku }\end{array}$} & Děti a mládež & 37,3 \\
\cline { 2 - 3 } & Dospělí & 11,1 \\
\cline { 2 - 3 } & Různý věk nebo věkově smíšené skupiny & 51,6 \\
\hline \multirow{3}{*}{$\begin{array}{l}\text { Trénovaní sportovci } \\
\text { podle pohlaví }\end{array}$} & Jen dívky/ženy & 2,4 \\
\cline { 2 - 3 } & Jen chlapci/muži & 10,4 \\
\cline { 2 - 3 } & Dívky/ženy i chlapci/muži & 87,2 \\
\hline \multirow{4}{*}{$\begin{array}{l}\text { Trenérské působení ve spor- } \\
\text { tu (celkem 42 sportů) }\end{array}$} & Atletika & 12,3 \\
\cline { 2 - 3 } & Fotbal & 11,8 \\
\cline { 2 - 3 } & Volejbal & 6,6 \\
\cline { 2 - 3 } & Plavání & 6,1 \\
\cline { 2 - 3 } & Basketbal & 4,2 \\
\cline { 2 - 3 } & V dalších 37 sportech & 59,0 \\
\hline
\end{tabular}

\section{VÝSLEDKY}

\section{Cesta ke sportu}

Začátky sportování současných trenérů (podrobněji tab. č. 2) podstatně ovlivnili v 76,4\% jejich rodiče, dále jejich kamarádi $(57,6 \%)$ a učitelé ve škole ( $42,7 \%$; součet netvoří $100 \%$, protože si respondenti mohli vybrat i více odpovědí). Rodiče preferovali především sport pro zdraví $(41,5 \%)$, dále soutěžní $(38,2 \%)$ a vrcholový sport (18,4 \%). Významný impuls představoval zvláště vzor otců, kteří sportovali častěji $(86,8 \%)$ než matky budoucích trenérů $(71,7 \%)$. Naprostá většina současných oslovených trenérů v mládí rekreačně nebo soutěžně sportovala. Začátky svého sportování si oslovení trenéři často spojují s pozitivní sociální atmosférou („Vybavím si spoustu kamarádů a radostné prožitky z vítězství...") a pro jejich trenérskou práci tvoří významný zdroj empirie („Přesně vidím to, jak začínají mí svěřenci.“).

Tabulka č. 2: Názory trenérů na jejich cestu ke sportu (údaje v procentech, $\mathrm{N}=212$ )

\begin{tabular}{|l|c|c|c|c|c|}
\hline \multirow{2}{*}{$\begin{array}{l}\text { Moje sportovní působení ovlivnily zejména } \\
\text { tyto okolnosti: }\end{array}$} & \multicolumn{2}{|c|}{ souhlasím } & \multicolumn{2}{|c|}{ nesouhlasím } & \multirow{2}{*}{$\begin{array}{c}\text { nemohu se } \\
\text { vyjádřit }\end{array}$} \\
\cline { 2 - 5 } & zcela & spíše & spíše & vůbec & 5,7 \\
\hline rodina (i širší) & 43,4 & 33,0 & 9,9 & 8,0 & 5,8 \\
\hline kamarádi & 20,8 & 36,8 & 21,7 & 12,7 & 8,7 \\
\hline škola - učitelé & 15,1 & 27,6 & 23,1 & 20,3 & 13,9 \\
\hline
\end{tabular}

\section{Cesta $k$ trenérské profesi}

Okolnosti, které u námi zkoumaného vzorku sportovních trenérů determinovaly jejich cestu k trenérské profesi, jsme zjištovali pomocí 22 dotazníkových položek. Dvě položky měly formu neukončené věty a zjištovaly, ve kterých sportech oslovení trenéři působí. Dalších 19 položek měřilo za využití Likertovy škály názory a postoje zkoumaných trenérů k okolnostem vstupu do trenérské profese (viz tab. č. 3). Závěrečná položka této části dotazníku měla opět formu neukončené věty - „Chtěl/a jsem být trenérem/ trenérkou, protože ...." K této problematice se nám také vyjádřili někteří trenéři i v závěrečné otevřené položce celého dotazníku („Rád/a bych ještě k tématu dotazníku Cesta k trenérské profesi dodal/a, že ...").

Tabulka č. 3: Názory trenérů na jejich cestu k trenérství (údaje v procentech, $\mathrm{N}=212$ )

\begin{tabular}{|c|c|c|c|c|c|}
\hline \multirow{2}{*}{ Chtěl jsem být trenérem/trenérkou, protože: } & \multicolumn{2}{|c|}{ souhlasím } & \multicolumn{2}{|c|}{ nesouhlasím } & \multirow{2}{*}{$\begin{array}{c}\text { nemohu se } \\
\text { vyjádřit }\end{array}$} \\
\hline & zcela & spíše & spíše & vůbec & \\
\hline $\begin{array}{l}\text { Kvůli sportu jsem neměl/a čas na školu, tre- } \\
\text { nérství se nabízelo jako schůdná cesta }\end{array}$ & 3,9 & 5,5 & 17,1 & 62,4 & 11,1 \\
\hline
\end{tabular}




\begin{tabular}{|l|c|c|c|c|c|}
\hline $\begin{array}{l}\text { Chtěl/a jsem studovat jiný obor, ale } \\
\text { nedostal/a jsem se na zvolenou školu }\end{array}$ & 1,1 & 2,8 & 14,4 & 69,6 & 12,1 \\
\hline Tato profese mé lákala od dětství, líbila se mi & 22,1 & 33,2 & 22,1 & 16,0 & 6,6 \\
\hline Trenérství mi nabídli v oddíle & 48,6 & 41,4 & 5,0 & 3,3 & 1,7 \\
\hline Zranil/a jsem se a chtěl/a jsem zůstat u sportu & 5,5 & 8,3 & 10,5 & 67,4 & 8,3 \\
\hline Ztratil/a jsem motivaci k závodění & 3,9 & 16,0 & 11,1 & 60,0 & 9,0 \\
\hline Klesala má výkonnost & 3,9 & 18,2 & 19,3 & 49,8 & 8,8 \\
\hline Trenérství je rodinná tradice & 3,3 & 6,1 & 8,3 & 72,4 & 9,9 \\
\hline Bavilo mě pracovat s dětmi & 45,9 & 36,5 & 5,5 & 7,2 & 4,9 \\
\hline Chtěl/a jsem hodně cestovat & 8,8 & 21,0 & 26,6 & 34,8 & 8,8 \\
\hline Chtěl/a jsem předávat své zkušenosti & 48,1 & 35,9 & 8,3 & 4,4 & 3,3 \\
\hline Chtěl/a jsem pomáhat druhým k úspěchu & 51,2 & 37,6 & 5,0 & 0,0 & 6,2 \\
\hline $\begin{array}{l}\text { Myslel/a jsem, že je to pro- } \\
\text { fese s velkou prestiží }\end{array}$ & 9,4 & 16,6 & 29,8 & 35,9 & 8,3 \\
\hline $\begin{array}{l}\text { Myslel/a jsem si, že se trenér- } \\
\text { stvím dá vydělat dost peněz }\end{array}$ & 3,3 & 8,8 & 30,1 & 49,2 & 8,6 \\
\hline $\begin{array}{l}\text { Myslel/a jsem si, že trenér- } \\
\text { ství může vést ke slávě }\end{array}$ & 3,9 & 12,6 & 30.9 & 45,9 & 6,7 \\
\hline $\begin{array}{l}\text { Lákala mě atmosféra závodo̊ a chtěl/a } \\
\text { jsem se v ní pohybovat i nadále }\end{array}$ & 30,4 & 36,5 & 10,5 & 16,0 & 6,6 \\
\hline Atmosféra ve skupině sportovců se mi líbila & 54,1 & 35,4 & 3,9 & 3,9 & 2,7 \\
\hline Začal/a jsem trénovat své děti & 7,7 & 5,5 & 3,9 & 55,3 & 27,6 \\
\hline $\begin{array}{l}\text { Vždy jsem se zajímal/a o nové } \\
\text { poznatky v mém sportu }\end{array}$ & 50,1 & 35,9 & 6,1 & 2,2 & 5,7 \\
\hline
\end{tabular}

Z hlediska důvodů, které respondenti uvedli jako podstatné pro volbu své trenérské profese, měly největší zastoupení následující okolnosti:

- $\quad$ trenérství nabídli v oddíle $(90,0 \%)$

- dobrá atmosféra ve skupině sportovců $(89,5 \%)$

- $\quad$ snaha pomáhat druhým $\mathrm{k}$ úspěchu $(88,8 \%)$

- $\quad$ zájem o nové poznatky ve sportu $(86,0 \%)$

- přání předávat své zkušenosti $(84,0 \%)$

- $\quad$ zájem o práci s dětmi $(82,4 \%)$

- přitažlivá atmosféra závodů $(66,9 \%)$

- trenérská profese lákala od dětství (55,3\%).

\section{Vzdělávání trenérů}

V následující části se zaměříme na základní data, která se týkala pohledu vybraných aktivních sportovních trenérů na jejich vzdělávání a na možnosti dalšího vzdělávání. $Z$ tab. č. 4 je patrné, že většina oslovených trenérů $(80,2 \%)$ se domnívá, že je pro profesi trenéra dobře odborně připravena. U hodnocení adekvátnosti trenérského vzdělávání vzhledem $\mathrm{k}$ aktuálním potřebám současné praxe však vidíme velmi rozdílné názory, které řada trenérů blíže okomentovala v dalších otevřených položkách dotazníku (např̀. „vzdělávání mě připravilo snad skoro na všechno“, „je to spíše formalita, většinu věcí známe“). S často převažujícím názorem, že větší význam pro trenéra mají zkušenosti než absolvované vzdělání, souhlasila i většina dotázaných trenérů $(62,3 \%)$. V gradaci trenérské profese sehrává mimořádnou úlohu další vzdělávání. Zajímala nás proto jeho nabídka, kterou respondenti převážně označili jako širokou (58\%). Zásadní překážku v dalším profesním vzdělávání trenéři nevidí v dostupnosti z důvodu cestování, nedo- 
statku času a ani ve finanční náročnosti. Tím spíše bylo velmi překvapivé vyjádření pouhé pětiny trenérů, že rádi využívají možnosti dalšího vzdělávání.

Tabulka č. 4: Hodnocení trenérského vzdělávání (údaje v procentech, $\mathrm{N}=212$ )

\begin{tabular}{|l|c|c|c|c|c|}
\hline \multirow{2}{*}{} & \multicolumn{2}{|c|}{ souhlasím } & \multicolumn{2}{c|}{ nesouhlasím } & \multirow{2}{*}{ nemohu se } \\
\cline { 2 - 5 } & zcela & spíše & spíše & vůbec & vyáit \\
\hline $\begin{array}{l}\text { Myslím, že jsem pro profesi trené- } \\
\text { ra dobř́e odborně připraven/a }\end{array}$ & 21,7 & 58,5 & 11,3 & 0,5 & 8,0 \\
\hline $\begin{array}{l}\text { Vzdělávání trenérů pružně reagu- } \\
\text { je na měnící se potřeby praxe }\end{array}$ & 10,9 & 34,0 & 36,3 & 8,0 & 10,8 \\
\hline U trenéra hrají zkušenosti větší roli než vzdělání & 17,5 & 44,8 & 25,0 & 4,3 & 8,4 \\
\hline Nabídka dalšího vzdělávání pro trenéry je široká & 17,0 & 41,0 & 28.3 & 7,1 & 6,6 \\
\hline Rád/a využívám možnosti dalšího vzdělávání & 13,2 & 6,6 & 1,9 & 0,0 & 78,3 \\
\hline $\begin{array}{l}\text { Nemám dostatek příležitostí } \\
\text { sdílet své profesní záležitosti s kolegy }\end{array}$ & 5,2 & 31,1 & 33,5 & 20,8 & 9,4 \\
\hline $\begin{array}{l}\text { Další profesní vzdělávání je pro mne jen } \\
\text { obtížně dostupné z důvodu cestování }\end{array}$ & 0,9 & 10,9 & 34,4 & 40,1 & 13,7 \\
\hline $\begin{array}{l}\text { V dalším profesním vzdělává- } \\
\text { ní mi brání nedostatek času }\end{array}$ & 5,7 & 31,1 & 30,2 & 26,4 & 6,6 \\
\hline $\begin{array}{l}\text { V dalším profesním vzdělávání mi } \\
\text { brání především jeho finanční náročnost }\end{array}$ & 7,6 & 23,6 & 34,4 & 25,5 & 8,9 \\
\hline
\end{tabular}

Při hodnocení svého trenérského vzdělávání na sportovních fakultách vysokých škol se skoro polovina oslovených trenérů domnívá $(49,4 \%)$, že je toto vzdělání zejména dobře připravilo po stránce teoretické. Samu „teorii“ hodnotí jak pozitivně (zejména ocenění získaných znalostí, např. z anatomie, fyziologie nebo z teorie sportovního tréninku), tak - a to je častější případ - velmi negativně („teorie, která je skoro $k$ ničemu“). Ǩada trenérů, absolventů sportovních fakult, oceňuje své získané vzdělání i jako dobrou př́pravu pro praxi (47 \%). Pouze sporadicky se objevují výroky, které absolvované vzdělávání oceňují jako impulz k vlastnímu rozvoji a dalšímu vzdělávání. Přes polovinu absolventů sportovních vysokých škol se současně domnívá, že je studium nepřipravilo pro praxi $(57,8 \%)$ - zde se mezi zcela převažujícími kusými odpovědmi objevilo i několik konkrétnějších vymezení (např. nepřipravenost na „řěsení problémů s motivací a kázní", na „sociální a psychologické problémy“ ad.).

Oslovení absolventi trenérských kurzů oceňují v menší míře než bývalí studenti sportovních fakult získané teoretické znalosti $(25,6 \%)$. I u nich se setkáváme s pozitivním oceněním získaných znalostí, včetně jejich chápání jako impulzu pro další vzdělávání, ale i s jejich kritikou. Trenérské kurzy považuje za dobrou prŕpravu pro praxi jen asi pětina oslovených trenérů $(21,7 \%)$. K oblastem, které absolventy trenérských kurzů málo připravily na jejich působení v praxi, patří stejně jako u absolventů sportovních fakult sociální aspekty (napřr. komunikace, motivace nebo řešení interpersonálních problémů). Pedagogické a psychologické aspekty trenérství současně představují i nejčastěji uváděnou oblast (29,7 \%), kterou námi oslovení trenéři zmiňují jako potřebnou v jejich dalším vzdělávání. Na druhém místě se pouze v 4,7 \% př́ípadů objevila teorie sportovního tréninku.

\section{Profesní kariéra}

$\mathrm{Z}$ tab. č. 5 je patrné, že většina oslovených sportovních trenérů (71,6\%) považuje trenérství za celoživotní profesi. Uvedené zjištění reflektuje vysokou náročnost a komplexnost zkoumané profese a současně reaguje na skutečnost, že cesta $k$ trenérské profesionalitě je poměrně dlouhá. Souvisí s náročným několikastupňovým trenérským vzděláváním, se zvyšujícím se důrazem na kvalitní odbornou př́pravu i s typickým rysem sociálních profesí - potřebou projít celou řadou fází profesního růstu od pomocné- 
ho trenéra až po vyzrálého odborníka, který může zastávat poradenskou pozici nebo pomáhat se vzděláváním svých kolegů.

Tab. 5: Hodnocení trenérské profesní kariéry (údaje v procentech, $\mathrm{N}=212$ )

\begin{tabular}{|c|c|c|c|c|c|}
\hline & \multicolumn{2}{|c|}{ souhlasím } & \multicolumn{2}{|c|}{ nesouhlasím } & \multirow{2}{*}{$\begin{array}{l}\text { nemohu se } \\
\text { vyjádřit }\end{array}$} \\
\hline & zcela & spíše & spíše & vůbec & \\
\hline Trenérství je celoživotní profesí & 33,9 & 37,7 & 16,5 & 6,6 & 5,3 \\
\hline Někdy zvažuji, že trenérství raději zanechám & 4,7 & 22,2 & 39,2 & 22,6 & 11,3 \\
\hline V trenérství nelze dosáhnout velké kariéry & 4,7 & 23,6 & 41,1 & 24,1 & 6,5 \\
\hline $\begin{array}{l}\text { Trenérství je hodně fyzicky } \\
\text { i psychicky namáhavá profese }\end{array}$ & 47,6 & 39,2 & 8,9 & 0,5 & 3,8 \\
\hline $\begin{array}{l}\text { Úspěšným trenérem může být pouze ten, } \\
\text { který byl dříve úspěšným sportovcem }\end{array}$ & 5,2 & 14,6 & 40,1 & 33,0 & 7,1 \\
\hline $\begin{array}{l}\text { Trenéŕi často také podnikají, a to jim } \\
\text { usnadňuje jejich působení v profesi }\end{array}$ & 11,3 & 38,7 & 23,6 & 8,0 & 18,4 \\
\hline $\begin{array}{l}\text { Pokud jsou trenéři zároveň funkcionáři } \\
\text { v oddílech, usnadňuje jim to jejich práci }\end{array}$ & 15,6 & 36,3 & 25,5 & 7,5 & 15,1 \\
\hline $\begin{array}{l}\text { Vzdělání trenéra má přímý vliv na jeho } \\
\text { kariéru a finanční ohodnocení }\end{array}$ & 15,6 & 36,3 & 24,5 & 11,3 & 12,3 \\
\hline $\begin{array}{l}\text { Práce s dospělými sportovci je méně } \\
\text { zátěžová než práce s dětmi }\end{array}$ & 14,2 & 34,9 & 25,0 & 13,2 & 12,7 \\
\hline
\end{tabular}

$\mathrm{Na}$ vysokou náročnost trenérství reagovala druhá položka v části našeho dotazníku věnované kariéře sportovních trenérů. S výrokem „Někdy zvažuji, že trenérství raději zanechám“ nesouhlasilo 61,8\% oslovených trenérů. Toto pozitivní zjištění koreluje s předešlou položkou, ve které většina námi oslovených trenérů považovala trenérství za celoživotní profesi. Pro řadu sociálních profesí bývá typická tzv. plochá profesní kariéra, tzn. nemožnost dosáhnout ve svém kariérním růstu výrazného zvýšení postavení a prestiže, včetně vysokého finančního ohodnocení. Zejména zásluhou široké medializace sportu se může na první pohled zdát, že lze v trenérství často dosahovat skvělé kariéry. Kdybychom ale porovnaly celkové počty aktivních sportovních trenérů (celkové statistické údaje bohužel nejsou k dispozici) s počtem mediálně známých, úspěšných a finančně nadprůměrně ohodnocených trenérů, patrně zjistíme, že pravděpodobnost strmého kariérního postupu není v trenérství také vysoká. Převážná část trenérů se věnuje především mládeži a mnozí z nich se spíše potýkají s nedostatečným ekonomickým zázemím. Přesto se 65,2\% námi oslovených trenérů domnívá, že v trenérství lze dosáhnout velké kariéry.

Mimořádnou náročnost trenérské profese potvrdili námi oslovení sportovní trenéři $-86,8 \% \mathrm{z}$ nich se domnívá, že trenérství je hodně fyzicky i psychicky namáhavá profese. V této oblasti se respondenti přiklánějí $\mathrm{k}$ názoru, že $\mathrm{z}$ hlediska věku sportovců je práce s dospělými sportovci méně zátěžová než práce s dětmi. V souvislosti s uvedenou náročností trenérské profese nás zajímaly některé okolnosti, které mohou její výkon usnadňovat. S výrokem „Trenéř často také podnikají, a to jim usnadňuje jejich pưsobení v profesi“ souhlasí 40,0\% respondentů (respektive u kladných odpovědí převažovali ti, kteří spíše souhlasí - 38,7 \%), nesouhlasilo s tímto názorem 31,6 \% dotázaných. U této položky se současně objevilo nejvíce respondentů, kteří využili odpovědi $\mathrm{N}$ - nemohu se vyjádřit (28,4 \%). Převažující souhlas (51,9\%) vyjádřili respondenti i s výrokem „Pokud jsou trenéři zároveň funkcionáři v oddílech, usnadñuje jim to jejich práci“.

Ačkoliv se „v žádném př́ípadě neprokázalo, že by existovala ,přímá úměra mezi úrovní sportovní (trenér jako bývalý hráč) a odváděnou úrovní trenérské práce“ (Jansa; Kocourek; Kovář 2009, s. 59), přesto nejen mezi širokou veřejností, ale často i ve vedení některých sportovních klubů převládá názor, že „úspěšným trenérem může být pouze ten, který byl dřive úspěšným sportovcem“. S takto formulovaným tvrzením, které - pokud je sportovním managementem preferováno nad významem absolvovaného kva- 
litního trenérského vzdělávání - přispívá mj. k nižšímu socioprofesnímu statusu sportovních trenérů (hovoří se např. o tzv. semiprofesi) - respondenti většinou nesouhlasili $(73,1 \%$, pouze $5,2 \%$ oslovených aktivních trenérů s tímto výrokem zcela souhlasilo). Př́mou souvislost trenérského vzdělávání s rozvojem kariéry a finančním ohodnocením trenéra uznává $51,9 \%$ respondentů. Pouze $15,6 \%$ procent oslovených trenérů je však o této závislosti zcela přesvědčeno, a naopak 35,8 \% souvislost nevidí.

\section{DISKUSE}

\section{Cesta ke sportu}

Výsledky empirického šetření ukázaly vybrané okolnosti, jež souvisí s cestou ke sportu a k trenérství, s trenérským vzděláváním a s profesní kariérou u výzkumného souboru aktivních sportovních trenérů. Některá výzkumná data potvrdila obecnější tendence, jež se objevily v zahraničních i českých výzkumech (např. Schierz; Thiele; Fischer 2006, Svoboda, 1998; Jansa, Kovář 2008a, 2008b). Jde např. o převahu trenérů mužů $(64,2 \%)$ nad trenérkami ženami, o fakt, že většina trenérů prošla vlastní aktivní závodní kariérou $(62,4 \%)$ a že sportovní orientaci ovlivnila především rodina a zejména otcové, kteři častěji sportovali než matky budoucích trenérů. Vzpomínky na vlastní sportovní začátky a na svou sportovní kariéru tvoří významný zdroj konkrétních zkušeností trenérů pro současnou praxi.

\section{Cesta $k$ trenérské profesi}

Pozitivní je zjišsění, že většina oslovených trenérů projevovala o tuto profesi výrazný zájem již v mládí a k hlavním motivům pro trenérství patřila vlastní práce s dětmi, předávání sportovních zkušeností, hlubší zájem o daný sport a především snaha pomáhat druhým k úspěchu. Se sociální orientací trenérské profese pozitivně koreluje předpokládaná pozitivní sociální atmosféra u skupiny sportovců, jako jeden z hlavních motivů pro výběr této profese. Naopak předpoklad získání vyššího finančního ocenění a společenské prestiže nehrál výraznější roli. Motivaci pro výkon trenérské profese ilustrují následující výpovědi „Chtěl jsem dokázat, že to jde i jinak - lépe!“, „Láska k mému sportu po ukončení etapy vrcholového sportu se promitla automaticky v trenérskou dráhu. To jsem věděl od svých 16 let a vlastnè veškeré studium, volbu školy atd. jsem podřizoval možnosti co nejkvalitnější sportovní př́pravy... Velkou úlohu na konečném rozhodnutí věnovat se trenérské dráze mělo pro mě osobni setkání s trenérskými kapacitami... To byly obrovské motivační impulsy právě pro trenérskou dráhu."

Trenérství patřri mezi sociální profese, pro které je podstatná práce s lidmi a adekvátní sociální jednání. Předpokládali jsme proto, že právě sociální aspekty budou sehrávat významnou roli již při volbě trenérské profese. Získaná data u vybraného vzorku sportovních trenérů uvedený předpoklad potvrdila. K nejčastěji uváděným okolnostem volby trenérské profese patřily právě sociální aspekty - pozitivní atmosféra ve skupině sportovců, pomoc druhým, předávání zkušeností, práce s dětmi a přitažlivá atmosféra závodů. Uvedené zjištění ilustrují i některé odpovědi zkoumaných trenérů na otevřenou položku v dotazníku Chtělla jsem být trenérem/trenérkou, protože...: „Di̊vodem byla dobrá parta“, „Jsem chtěla smysluplně vyplňovat dětem volný čas", „Chtěl jsem dokázat, že to jde i jinak - lépe!“, „Velkou úlohu na konečném rozhodnutí věnovat se trenérské dráze mělo pro mě osobni setkáni s trenérskými kapacitami... To byly obrovské motivační impulsy právě pro trenérskou dráhu“.

S podobným výroky trenérů jsme se setkali i v závěrečné otevřené položce celého dotazníku:

- „Vztah k trénování se dlouhodobě vyvijí, je velmi ovlivněn i tím, pod rukama jakých trenérú člověk $v$ životě sám projde a s jakými trenéry se potká. Domnívám se, že velkou výhodou je, když má možnost jak srovnáni většího množství trenérü, tak možnost potkat se s velmi dobrými i horšími ažšsatnými trenéry (jak lidsky, tak profesně). Pokud je člověk vnímavý a dokáže se nad jejich prací zamýšlet, dá mu to obrovský kus zkušeností a znalostí do budoucí vlastní trenérské praxe."

- „Trenérská práce se vším všudy nemůže být, zaměstnáním. Pro mě osobně je to spiš kontinuita snu $z$ mládí (vrcholové sportovní dráhy), kde jsem mohl zažít nějaké výjimečné okamžiky a zkusit toto samé dokázat na té druhé straně mince - trenérském postu. Dlouhou dobu jsem neměl trenéra, učili 
jsme se od staršich hráčů. I nášsport je dnes úplně někde jinde, než před 20 lety. Jak důležitýa nápomocný může být trenér pro sportovce na této dráze - bylo i moje obrovské poznání."

- „Já už nemohla dosáhnout cíle, ke kterému jsem směřovala, tak se snažím adekvátně a plynule pomáhat někomu jinému, aby to dokázal... Aby jednou stál na tom nejvyšším stupínku a zahrála mu naše hymna... A taky se chci podílet na propagaci pohybu dál a všem..."

I u zcela dominantní okolnosti pro volbu trenérské profese (Trenérství mi nabídli v oddíle), kterou uvedlo $90 \%$ oslovených trenérů, lze předpokládat, že v řadě př́padů souvisela se sociálními vztahy v daném oddíle. Uvedený předpoklad ilustrují výpovědi trenérů: „Chtěl jsem být trenérem, protože bylo třeba pomoci oddílu“, „Chtěla jsem být trenérkou, protože mě premluvily mladé hráčky“.

\section{Vzdělávání trenérů}

Podstatu vzdělávání sportovních trenérů tvoří proces učení, v němž se budoucí (popř. současní) trenéři učí trénovat (Trudel; Gilbert 2006, s. 516). Vzdělávání trenérů v praxi pak probíhá zejména dvojí cestou - systematicky v rámci trenérských kurzůa dále spíše nahodile, kdy vychází ze zkušeností a z reflexe trenérovy praxe. Sportovní trenérství svým zařazením mezi pedagogické profese předpokládá provázanost $s$ celoživotním vzděláváním podobně, jak je tomu například v učitelství. Zdá se však, že učitelé mají možnost využívat podstatně širší a propracovanější nabídky dalšího vzdělávání a pestřejší formy profesionálního rozvoje (zahraniční kurzy, kolegiální návštěvy, práce na projektech školy apod.). Vzdělávání učitelů současně poutá pozornost mnohých odborníků i zákonodárců, rozvoj trenérství je obvykle odkázán víceméně jen na aktivity sportovních fakult vysokých škol a sportovních svazů.

$\mathrm{V}$ evropském kontextu se vzděláváním trenérů zabýval rozsáhlý projekt AEHESIS, ve kterém bylo zapojeno 28 zemí s cílem zpracovat vědeckou expertízu trenérské práce za posledních 20 let $\mathrm{v}$ jednotlivých sportech a zemích a následně připravit vzdělávací standardy pro sportovní profese (Petry; Froberg; Madella 2006). I v globálním měřítku, např̀ v rámci aktivit ICCE (International Council for Coach Education), výrazně sílí požadavek profesionalizace trenérské práce a přesného vymezení profilu trenérského vzdělávání.

V soudobých především zahraničních koncepcích trenérského vzdělávání se stále častěji zdůrazňuje nutnost těsněji propojit teorii a praxi a prohloubit sociálněvědní a etické aspekty trenérství (podrobněji Jůva 2006, 2008, Schierz; Thiele; Fischer 2006). Analogické tendence naznačily i výsledky našeho dotazníkového šetření, kde respondenti upozorňují na nedostatečné propojení teorie s praxí a její reflexi: „Možná by bylo vhodné více propojit teorii s praxí při vzdělávání trenérů! Př́mo v praxi vzít něco z teorie a ř́ci: tohle jsi se učil proto, aby jsi to ted'použil! Někdy se zdá teorie hodně vzdálená od praxe - pokud budou trenéři vědět, proč se to uči (chápat to), bude větši motivace." Pozitivní je zjištění, že oslovení trenéŕi ve velké míře vyjadřují se vzděláváním alespoň částečnou spokojenost a řada $\mathrm{z}$ nich zdůrazňuje význam dalšího vzdělávání: „Každý trenér by se měl neustále vzdělávat a zajímat se o nejnovější poznatky jak z praxe, tak teorie. "Trenérství „je neustálé učení se nových poznatkì, teorií a získávání dưležitých zkušeností“. Ve svém dalším profesním vzdělávání pak respondenti nejčastěji zdůrazňují potřebu rozvoje v psychologických, pedagogických a etických aspektech trenérství. Na závěr uved’me jednu z výpovědí oslovených trenérů, jež výstižně charakterizuje potřebné akcenty graduálního i dalšího trenérského vzdělávání: „Dnes existuje spousta materiálů, jak sestavit vhodný tréninkový plán, jak kondičně optimálně pripravit sportovce. Ale ve sportu, a zvláště ve sportovních hrách, je nespočet proměnných, na které musí trenér vhodnè reagovat. A to souvisís morálkou, charakterem, etikou a předvídavostí. Proto si myslím, že osobnost (charakterové vlastnosti) trenéra je nejdůležitějším prvkem pro úspěch v trenérské profesi."

$\mathrm{V}$ závěru části dotazníku $\mathrm{k}$ trenérskému vzdělávání trenéři-respondenti doplňovali nedokončenou větu („Ke vzdělávání trenérů bych chtěl/a dodat, že ...") zejména opětovným zdůrazněním nutnosti propojení teorie a praxe ve vzdělávání trenérů. Upozorňují na to, že nové společenské podmínky a okolnosti sportovního života mění pohled na další vzdělávání a podtrhují jeho důležitost. Zároveň jsou si vědomi tohoto, že účast v dalším vzdělávání předpokládá trvalou osobní motivaci k profesionálnímu rozvoji. Př́stup ke vzdělávání však mohou, podle některých trenérů, komplikovat i vnější faktory - např. nedo- 
statek specificky zaměřeného vzdělávání pro trenéry „malých sportưđ, nedostatečné uplatnění mladých trenérů ap.

Získané výsledky naznačily, že převážná většina respondentů je zcela nebo alespoň spíše spokojena se svým vzděláním a s přípravou na profesi. Oslovení trenéři ve většině př́ípadů tvrdí, že rádi využívají možností dalšího vzdělávání, avšak zároveň vyjadřují jisté pochybnosti ve vztahu k nabídce dalšího vzdělávání. Zdá se, že z pohledu trenérů hraje významnou roli profesionální zkušenost. Většina trenérů jí dává přednost před vzděláváním; pravděpodobně se tedy trenéři (podobně jako zástupci řady jiných profesí, např. učitelů) efektivně učí a zdokonalují svou profesionalitu až teprve v praxi samotné. Nezodpovězenou otázkou zůstává výměna, sdílení, resp. reflexe praktických zkušeností. Možnosti výměny zkušeností a sdílení problémů praxe vnímají trenéři velmi nejednotně a mnohdy i kontradiktivně. Drtivá většina dotazovaných vyjadřuje alespoň zčásti nenaplněnou potřebu výměny zkušeností, zároveň však řada $\mathrm{z}$ nich udává, že př́ležitosti $\mathrm{k}$ výměně zkušeností má. Znamená to patrně, že jejich vzdělávací potřeba ve smyslu výměny zkušeností je jen částečně saturovaná.

Preference praktické zkušenosti se odráží i do názorů a postojů zkoumaných trenérů ke vzdělávání a dalšímu vzdělávání, které respondenti vyjadřovali v reakcích na nedokončené věty („Studium na vysoké škole/trenérské kurzy mě dobře připravilo na ..., ale nepřipravilo na ...". „Potřeboval/a bych dalši vzdělávání zejména v oblasti ..."). Respondenti uvádějí, že jim studium na vysoké škole či trenérské kurzy přinesly spíše jen teoretické vzdělání a všeobecné poznatky o práci trenéra v konkrétním sportu. Pouze jako sporadické informace získali poznatky o práci s dětmi. Ojediněle, ale přesto, někteří trenéři odpovídali, že jim vzdělávání nepřineslo nic. V souladu s výše zmíněným trenéři sdělují, že je vysoké školy a trenérské kurzy nenaučily zvládat praxi, a to zejména $\mathrm{v}$ oblasti řešení problémů se svěřenými sportovci. Oslovení trenéři současně citelněji postrádali psychologii sportu v její praktické podobě a také nácvik specifických dovedností zaměřených na zvládání konkrétních situací (didaktika sportu, herní situace ap.).

Potřeby trenérů v oblasti dalšího vzdělávání poněkud překvapují svou různorodostí a širokým záběrem. Trenéři vyjadřují potřebu dalšího vzdělávání vedle metodiky, techniky a biomechaniky daného sportu také $\mathrm{v}$ jazycích a $\mathrm{v}$ informační technologii, v psychologii sportu, andragogice, v regeneraci a výživě, $\mathrm{v}$ rehabilitaci, $\mathrm{v}$ ekonomice a marketingu. Zdá se, že pro úspěch v profesi je podle trenérů důležité zejména dobře zvládat „technické“ věci typické pro klasický trenérský přístup: jak naučit svěřence zvládnout techniku sportu a jak mu pomoci zvýšit výkon. Překvapilo nás, že trenéři ve značné míře pocitují nedostatek vzdělání v oblasti cizích jazyků a počítačových technologií. Otázkou zůstává, zda vyjadřovaný pocit nedostatku v těchto oblastech by byl dostatečnou motivací k návštěvě kurzů dalšího či celoživotního vzdělávání, kdyby se kurzy podobného typu v nabídce dalšího vzdělávání objevily (např. angličtina pro trenéry ap.).

\section{Profesní kariéra}

Empirické zkušenosti a teoretické koncepce charakterizují trenérskou profesi jako komplexní a velmi náročnou (např̀. Svoboda 2003, 2007, Trudel; Gilbert 2006, Zindel 2006). Trenérství představuje sociální profesi, která předpokládá adekvátní a odpovědné sociální jednání. Úspěšné vykonávání trenérské profese determinuje vedle odborné erudice a zvládnutí celé řady klíčových kompetencí i mnoho širších společenských, ekonomických a materiálních podmínek. Některé z těchto aspektů zdůraznilo i hodnocení trenérské profesní kariéry, které jsme získali prizmatem námi oslovených aktivních sportovních trenérů.

$\mathrm{Z}$ výzkumného šetření je zřejmé, že si i námi oslovení trenéři uvědomují náročnost své profese, a to zejména $\mathrm{v}$ souvislosti s vedením dětí a mládeže. Trenérská profesní kariéra prochází řadou fází, pro jejichž gradaci je klíčová inspirace odborně i lidsky kvalitními kolegy, permanentní vzdělávání a sebevzdělávání i vlastní sebereflexe. Jeden z oslovených trenérů tuto skutečnost vyjádřil takto: „Vztah k trénování se dlouhodobè vyvíjí, je velmi ovlivnèn i tím, pod rukama jakých trenérü člověk v životě sám projde a s jakými trenéry se potká. Domnivám se, že velkou výhodou je, když má možnost jak srovnání většího množství trenérů, tak možnost potkat se s velmi dobrými i horšimi až špatnými trenéry (jak lidsky, tak profesně). Pokud je člověk vnímavý a dokáže se nad jejich prací zamýšlet, dá mu to obrovský kus zkušeností 
a znalostí do budoucí vlastní trenérské praxe. "Současně je pro výkon této profese potřebné osobní zaujetí, jak je formuloval závěr jednoho z vyplněných dotazníků: „Snad jen, že trenéra může opravdu dělat jen ten, kdo svi̊j sport opravdu miluje. Jinak skončí, dřív než začal."

\section{Závěry}

Výsledky empirického šetření ukázaly vybrané okolnosti volby trenérské profese a její rozvoj u výzkumného souboru aktivních sportovních trenérů. Vzhledem k charakteru výzkumného vzorku nemůžeme své závěry zobecňovat na širší trenérskou populaci. V závěrech se však ukázala řada okolností, které jsou analogické s vybranými teoretickými koncepcemi trenérství a s obdobně zaměřenými empirickými výzkumy. Naprostá většina námi zkoumaných současných sportovních trenérů sportovala již v mládí. Ke sportu je pak přivedli zejména rodiče. K hlavním motivům pro volbu trenérství, o které současní trenéři často projevovali výrazný zájem již v mládí, patřila potřeba věnovat se zejména dětem, předávat vlastní sportovní zkušenosti, intenzivní zájem o daný sport a především úsilí pomáhat druhým $\mathrm{k}$ úspěchu. K dalším důležitým motivům, které sehrály významnou roli při volbě trenérství, patřila očekávaná pozitivní sociální atmosféra při práci se sportovci. Ekonomické aspekty trenérské práce naopak nebyly pro volbu trenérské profese významné.

Podstatné východisko pro zkvalitnění své velmi náročné a komplexní profese oslovení trenéři převážně vidí - stejně jako naši i zahraniční odborníci - v trenérském vzdělávání, které by mělo v profesní dráze trenéra gradovat ve formě odborné pomoci a poradenství mladším kolegům. Výstižně tuto potřebnou tendenci vyjádřil jeden $\mathrm{z}$ našich respondentů: „Každý trenér by se měl neustále vzdělávat a zajímat se o nejnovější poznatky jak $z$ praxe, tak $z$ teorie. Já si momentálně dodělávám trenérství 1. tř́dy a doufám, že se budu moci podílet na vzděláváni trenérü nižšich tříd. V dnešní době je vhodné kromě publikací trenérưm nabídnout i výukové multimediální materiály v podobě DVD nebo prezentací na internetu. Určitě se budu snažit náš sport rozvijet a pokusím se poznatky předávat dalším trenérům. "Uvedená zjištění představují aktuální výzvu pro hledání optimální organizační, obsahové a didaktické koncepce trenérského vzdělávání a zejména pro rozvoj nových forem dalšího vzdělávání sportovních trenérů.

\section{Literatura:}

AYALON, A. What makes a coach a good teacher. In SIMRI, U.; TIEGEL, G. (eds.). The physical educator and the coach. Similarities and dissimilarities. Wingate: Institute for Physical Education. 1977, s. 59-64. BETTE, K.-H. Die Trainerrolle im Hochleistungssport : system- und rollentheoretische Überlegungen zur Sozialfigur des Trainers. Sankt Augustin : Richarz, 1984. ISBN 3-88345-313-7.

BORGGREFE, C.; CACHAY, K.; THIEL, A. Sozialkompetenz von Trainerinnen und Trainern im Spitzensport. Köln : Strauß, 2006. ISBN 3-93939-084-4.

CÔTÉ, J. The Development of Coaching Knowledge. International Journal of Sports Science \& Coaching, 2006, roč. 1, č. 3, s. 217-222.

CUNNINGHAM, G. B.; BRUENING, J.; SARTORE, M. L.; SAGAS, M.; FINK, J. S. The Application of Social Cognitive Career Theory to Sport and Leisure Career Choices. Journal of Career Development, 2005, roč. 32, č. 2, s. 122-138.

CUNNINGHAM, G. B.; SAGAS, M.; ASHLEY, F. B. Occupational commitment and intent to leave the coaching profession: Differences According to Race. International Review for the Sociology of Sport, 2001, roč. 36, č. 2, s. 131-148.

DIGEL, H. Zukunftsperspektiven des Trainerberufs. Leistungssport, 2000, roč. 30, č. 6, s. 5-11.

JANSA, P.; KOCOUREK, J.; KOVÁř, K. Základy pedagogiky sportu. In: JANSA, P.; DOVALIL, J. a kol. Sportovní př́prava: vybrané kinantropologické obory $k$ podpoře aktivního životního stylu. Praha: Q-art, 2009, s. 38-71.

JANSA, P; KOVÁR̆, K. Názory a postoje trenérů v týmových sportech. In: Hry 2008: Výzkum a aplikace. Plzeň : ZU, 2008a, s. 113-119. 
JANSA, P; KOVÁR̆, K. Názory a postoje trenérů ve vybraných sportech. In: Současný sportovní trénink. Praha : UK, 2008b, s. 317-321.

JENKINS, S. P. R. Sports Science Handbook. Essex : Multi Science Publishing, 2005. ISBN 0-906522-37-4. JƯVA, V. Organizační a obsahové trendy trenérského vzdělávání. Studia sportiva, Brno : FSpS MU, roč. 2, 2008, č. 2, s. 55-70. ISSN 1802-7679.

JU゚VA, V. Trenér v normativní koncepci pedagogiky sportu. In: Sborník prací Fakulty sportovních studií. Brno : Masarykova univerzita, 2006, s. 49-65. ISBN 80-210-4136-6.

Katalog prací a kvalifikační predpoklady. Nařízení vlády č. 469/2002. Znění k 1. lednu 2007 [online]. 2007 [cit. 2010-01-19]. Dostupné na WWW: <http://www.mpsv.cz/files/clanky/3348/Katalog_praci.pdf>.

LAVAllEE, D. Career Awareness, Career Planning, and Career Transition Needs Among Sports Coaches. Journal of Career Development, 2006, roč. 33, č. 1, s. 66-79.

PETRY, K.; FROBERG, K.; MADELLA, A. (eds.) Thematic Network Project AEHESIS: Report of the Third Year. Cologne : Institute of European Sport Development \& Leisure Studies, German Sport University Cologne, 2006. ISBN 3-00-020476-8.

SEKOT, A. K sociálním aspektům profesní pozice trenéra. In: Sport jako sociálně-kulturnífenomén. Brno : Masarykova univerzita, 2006, s. 13-30. ISBN 80-210-4136-6.

SCHIERZ, M.; THIELE, J.; FISCHER, B. Fallarbeit in der Trainerausbildung: Möglichkeiten und Grenzen einer pädagogischen Professionalisierung. Köln : Sportverlag Strauß, 2006. ISBN 3-939390-92-5.

SVOBODA, B. Pedagogika sportu. Praha : Karolinum, 2003. ISBN 80-246-0156-7.

SVOBODA, B. Pedagogika sportu. 2. vyd. Praha : Karolinum, 2007. ISBN 978-80-246-1358-1.

SVOBODA, B. Trenéři a současný sport. Tělesná výchova a sport mládeže, 1998, č. 3, s. 37-43.

TREUTLEIN, G. Trainerrolle und Professionalisierung. In: HAAG, H.; HUMMEL, A. (eds.). Handbuch Sportpädagogik. Schorndorf : Verlag Hofmann, 2001, s. 455-460.

TRUDEL, P.; GILBERT, W. Coaching and Coach Education. In: KIRK, D.; MACDONALD, D.; ÓSULLIVAN, M. (eds.). The Handbook of Physical Education. London ad. : SAGE Publications, 2006, s. 516-539.

VALLANCE, B. Coach profile: Questions for Brent Vallance. Modern athlete and coach, 2009, roč. 47, č. 1, s. 43-44.

Zákon č. 563/2004 Sb., o pedagogických pracovnících a o změně některých zákonu․ Praha : MŠMT, 2004. ZINDEL, T. Die Befristung von Arbeitsverträgen mit Trainern im Spitzensport. Berlin : BWV, 2006. ISBN 3-8305-1263-5. 